\title{
2010 Honda Insight VIN 1748 Hybrid Electric Vehicle Battery Test Results
}

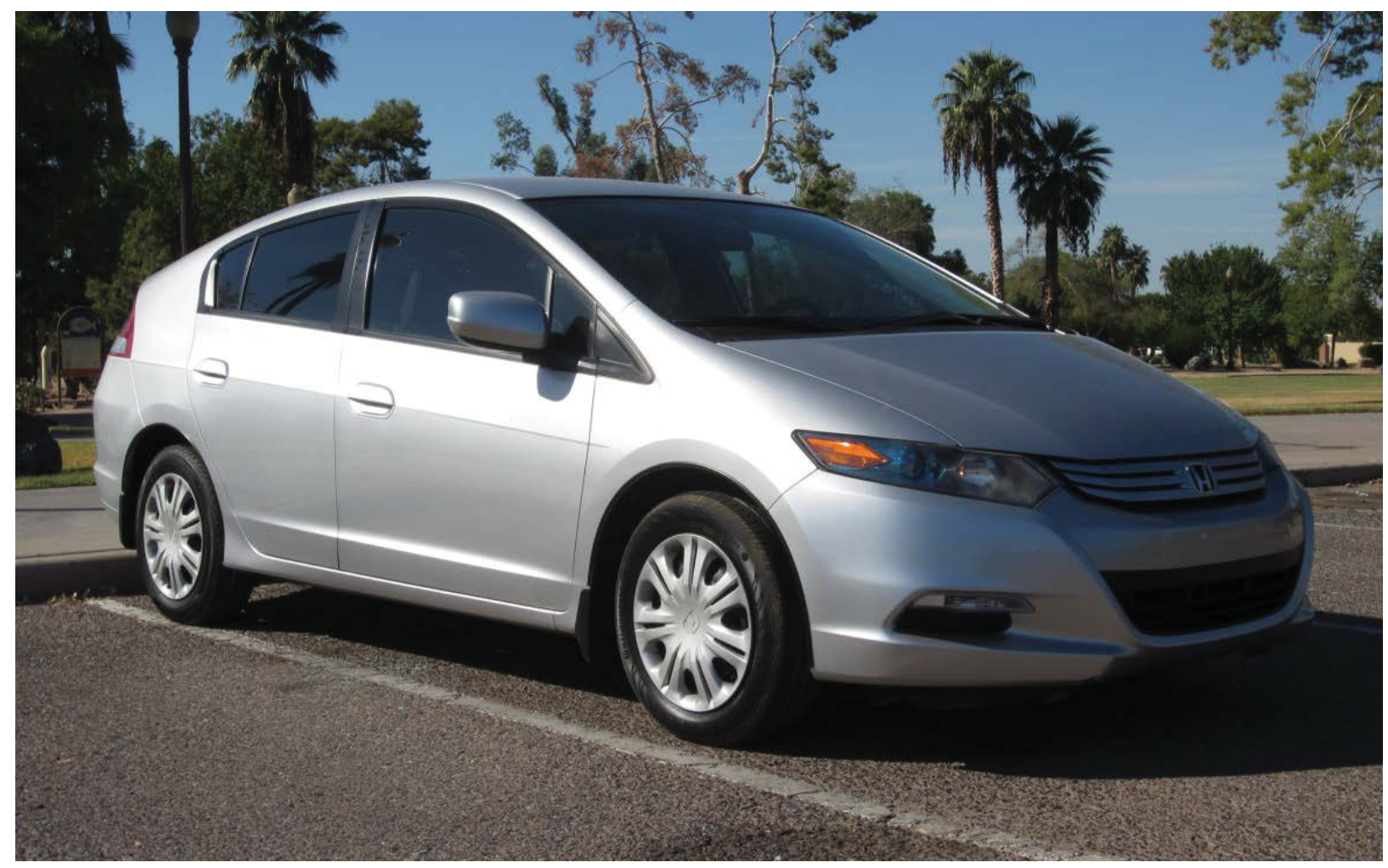

\section{Tyler Gray \\ Matthew Shirk}

January 2013

The Idaho National Laboratory is a U.S. Department of Energy National Laboratory Operated by Battelle Energy Alliance 
INL/EXT-13-28023

\title{
2010 Honda Insight VIN 1748 Hybrid Electric Vehicle Battery Rest Results
}

\author{
Tyler Gray ${ }^{1}$ \\ Matthew Shirk ${ }^{2}$
}

${ }^{1}$ ECOtality North America

${ }^{2}$ Idaho National Laboratory

January 2013

\begin{abstract}
Idaho National Laboratory
Idaho Falls, Idaho 83415
\end{abstract}

http://www.inl.gov

Prepared for the

U.S. Department of Energy

Assistant Secretary for Energy Efficiency and Renewable Energy

Under DOE Idaho Operations Office

Contract DE-AC07-05ID14517 


\section{DISCLAIMER}

This information was prepared as an account of work sponsored by an agency of the U.S. Government. Neither the U.S. Government nor any agency thereof, nor any of their employees, makes any warranty, expressed or implied, or assumes any legal liability or responsibility for the accuracy, completeness, or usefulness, of any information, apparatus, product, or process disclosed, or represents that its use would not infringe privately owned rights. References herein to any specific commercial product, process, or service by trade name, trade mark, manufacturer, or otherwise, does not necessarily constitute or imply its endorsement, recommendation, or favoring by the U.S. Government or any agency thereof. The views and opinions of authors expressed herein do not necessarily state or reflect those of the U.S. Government or any agency thereof. 


\begin{abstract}
The U.S. Department of Energy Advanced Vehicle Testing Activity Program consists of vehicle, battery, and infrastructure testing on advanced technology related to transportation. The activity includes tests on hybrid electric vehicles (HEVs), including testing the HEV batteries when both the vehicles and batteries are new and at the conclusion of 160,000 miles of on-road fleet testing. This report documents battery testing performed for the 2010 Honda Insight HEV (VIN: JHMZE2H59AS011748). Battery testing was performed by the Electric Transportation Engineering Corporation dba ECOtality North America. The Idaho National Laboratory and ECOtality North America collaborate on the Advanced Vehicle Testing Activity for the Vehicle Technologies Program of the U.S. Department of Energy.
\end{abstract}




\section{CONTENTS}

ABSTRACT

LIST OF FIGURES iv

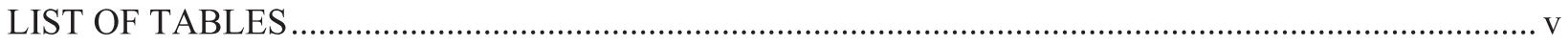

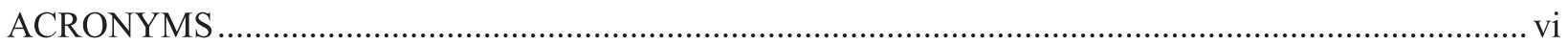

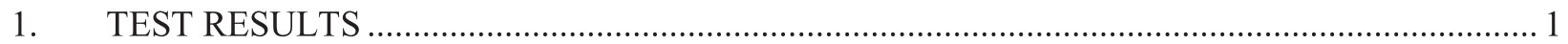

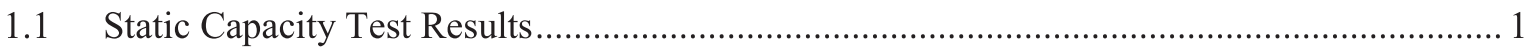

1.2 Hybrid Pulse Power Characterization Test Results........................................................... 1

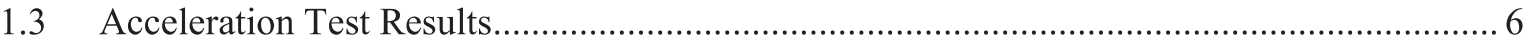

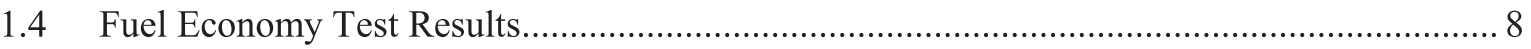

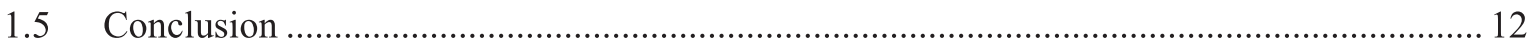

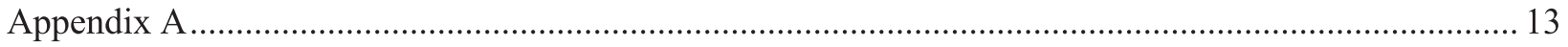

FIGURES

1. Voltage versus energy discharged during the static capacity test........................................... 2

2. Ten-second charge pulse resistance versus energy discharged............................................... 3

3. Ten-second charge pulse power capability versus energy discharged.................................... 3

4. Ten-second discharge pulse resistance versus energy discharged ......................................... 4

5. Ten-second discharge pulse power capability versus energy discharged .................................. 4

6. Peak discharge and regenerative power versus energy discharged ....................................... 5

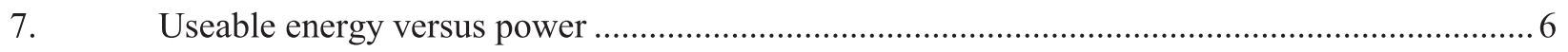

8. Battery power versus time from acceleration testing ......................................................... 7

9. Battery voltage versus time from acceleration testing ...................................................... 7

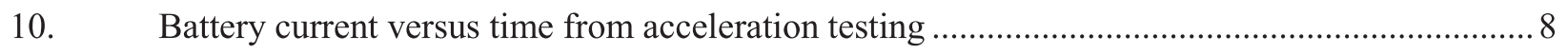

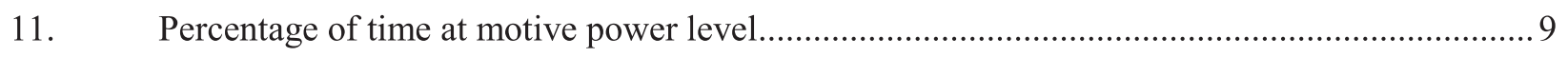

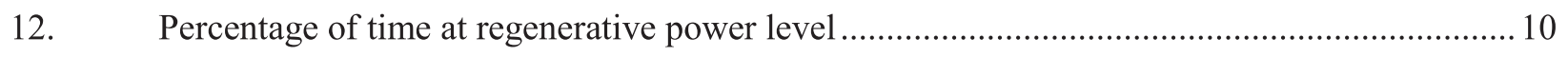




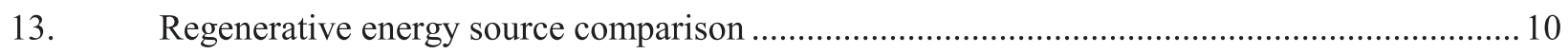

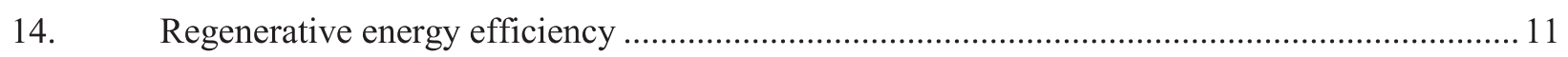

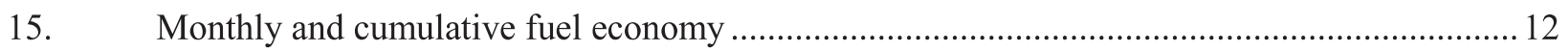

\section{TABLES}

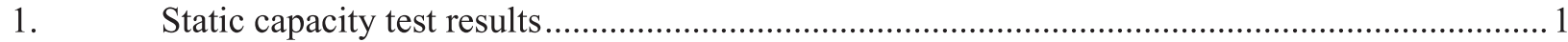

2. Hybrid Pulse Power Characterization test results.................................................................. 2

3. Acceleration test results for beginning-of-test and end-of-test on-track acceleration ................ 6

4. Battery performance results from the Urban Dynamometer Drive Schedule

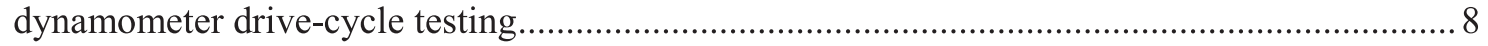




\section{ACRONYMS}

$\begin{array}{ll}\text { Ah } & \text { amp-hour } \\ \text { BOT } & \text { beginning of test } \\ \text { DOE } & \text { Department of Energy } \\ \text { EOT } & \text { end of test } \\ \text { HEV } & \text { hybrid electric vehicle } \\ \text { HPPC } & \text { Hybrid Pulse Power Characterization } \\ \text { kW } & \text { kilowatt } \\ \text { V } & \text { volt } \\ \text { VDC } & \text { volt direct current } \\ \text { VIN } & \text { vehicle identification number } \\ \text { Vpc } & \text { volt per cell } \\ \text { Wh } & \text { watt-hour }\end{array}$




\section{Honda Insight VIN 1748 Hybrid Battery Test Results}

\section{TEST RESULTS}

The U.S. Department of Energy (DOE) Advanced Vehicle Testing Activity Program consists of vehicle, battery, and infrastructure testing on advanced technology related to transportation. The activity includes tests on hybrid electric vehicles (HEVs), including testing the HEV batteries when both the vehicles and batteries are new (i.e., beginning-of-test or BOT) and at the conclusion of 160,000 miles of on-road fleet testing (i.e., end-of-test or EOT). This report provides test results for BOT and EOT battery testing conducted on a 2010 Honda Insight HEV, with VIN 1748 (full VIN: JHMZE2H59AS011748), from both laboratory and on-road test configurations. The battery laboratory test results include those from the static capacity test and the Hybrid Pulse Power Characterization (HPPC) Test. ${ }^{3}$ Vehicle test results include those from acceleration testing and fuel economy testing. ${ }^{4}$

The battery and vehicle testing was performed by the Electric Transportation Engineering Corporation dba ECOtality North America. The Idaho National Laboratory and ECOtality North America collaborate on the Advanced Vehicle Testing Activity for the Vehicle Technologies Program of DOE.

\subsection{Static Capacity Test Results}

Results from the laboratory BOT and EOT static capacity tests are provided in Table 1.

Table 1. Static capacity test results.

\begin{tabular}{lccccc}
\hline & Test Date & $\begin{array}{c}\text { Odometer } \\
(\mathbf{m i})\end{array}$ & $\begin{array}{c}\text { Rated Capacity } \\
\text { (Ah) }\end{array}$ & $\begin{array}{c}\text { Measured } \\
\text { Capacity (Ah) }\end{array}$ & $\begin{array}{c}\text { Measured } \\
\text { Energy (Wh) }\end{array}$ \\
\hline BOT & July 6, 2009 & 24 & 5.75 & 5.66 & 600 \\
EOT & April 6, 2012 & 160,016 & 5.75 & 5.71 & 590 \\
Difference & - & 159,992 & - & $-0.05(-0.9 \%)$ & $10(1.6 \%)$ \\
\hline
\end{tabular}

Figure 1 shows battery voltage versus energy discharged. This graph illustrates voltage values during constant-current discharge versus cumulative energy discharged from the battery at a $\mathrm{C} / 1$ constant-current discharge rate at BOT and EOT.

\subsection{Hybrid Pulse Power Characterization Test Results}

The HPPC test results are summarized in Table 2.

Figure 2 and Figure 4 illustrate the charge and discharge pulse resistance graphs of the battery, respectively. The internal resistance is depicted over a range of 10 to $90 \%$ depth of discharge, which is represented by the amount of energy discharged at each interval. Each curve represents the specified HPPC BOT or EOT resistance at the end of the 10-second pulse interval.

Figure 3 and Figure 5 illustrate the charge and discharge pulse power capability graphs of the battery, respectively. The power capability is depicted over a range of 10 to $90 \%$ depth of discharge, which is represented by the amount of energy discharged at each interval. Each curve represents the calculated HPPC BOT or EOT power capability at the end of the 10-second pulse interval at the cell voltage limits.

\footnotetext{
${ }^{3}$ Static Capacity and HPPC test procedures are based on the FreedomCAR Battery Test Manual for Power-Assist Hybrid Electric Vehicles, DOE/ID-11069, October 2003, Procedures 3.2 and 3.3, respectively. The measured capacity at BOT testing was used to determine the magnitude of current during all HPPC tests.

${ }^{4}$ Acceleration Testing and Fuel Economy Testing procedures were performed in accordance with the Advanced Vehicle Testing Activity HEVAmerica test procedures ETA-HTP02 and ETA-HTP03, respectively.
} 
Table 2. Hybrid Pulse Power Characterization test results.

\begin{tabular}{lcccccc}
\hline & $\begin{array}{c}\text { 10s Discharge } \\
\text { Power } \\
\text { Capability } \\
(\mathbf{k W})\end{array}$ & $\begin{array}{c}\text { 1s Discharge } \\
\text { Power } \\
\text { Capability } \\
(\mathbf{k W})\end{array}$ & $\begin{array}{c}\text { 10s Charge } \\
\text { Power } \\
\text { Capability } \\
\mathbf{( k W )}\end{array}$ & $\begin{array}{c}\text { 1s Charge } \\
\text { Power } \\
\text { Capability } \\
(\mathbf{k W})\end{array}$ & $\begin{array}{c}\text { Maximum } \\
\text { Cell Voltage } \\
(\mathbf{V})\end{array}$ & $\begin{array}{c}\text { Minimum } \\
\text { Cell Voltage } \\
(\mathbf{V})\end{array}$ \\
\hline BOT & 9.24 & 15.1 & 7.44 & 12.2 & 1.48 & 1.00 \\
EOT & 9.82 & 13.4 & 9.13 & 16.3 & 1.48 & 1.00 \\
Difference & $-0.58(-6.2 \%)$ & $1.7(11 \%)$ & $-1.69(-22 \%)$ & $-4.1(-33 \%)$ & - & - \\
\hline
\end{tabular}

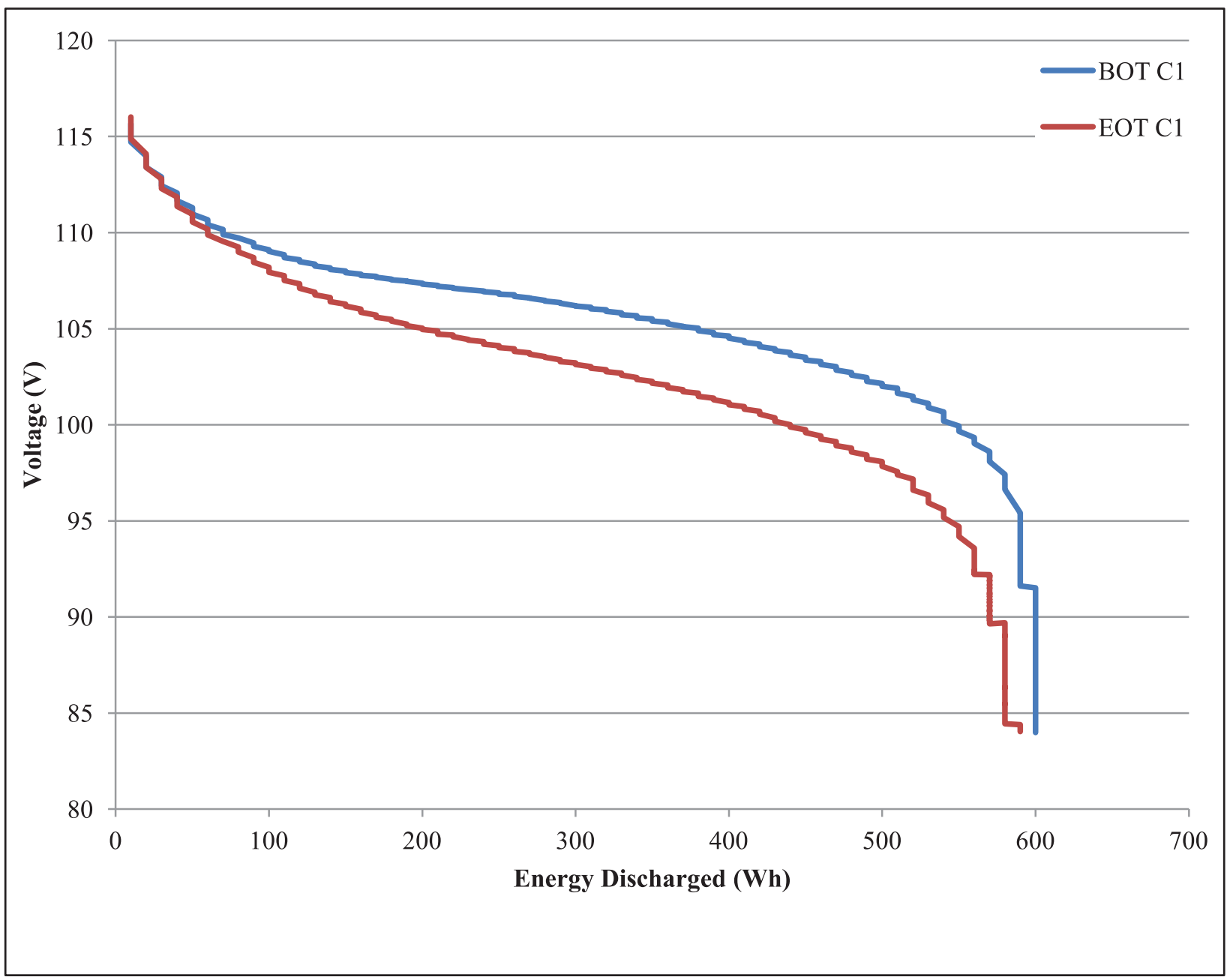

Figure 1. Voltage versus energy discharged during the static capacity test. 


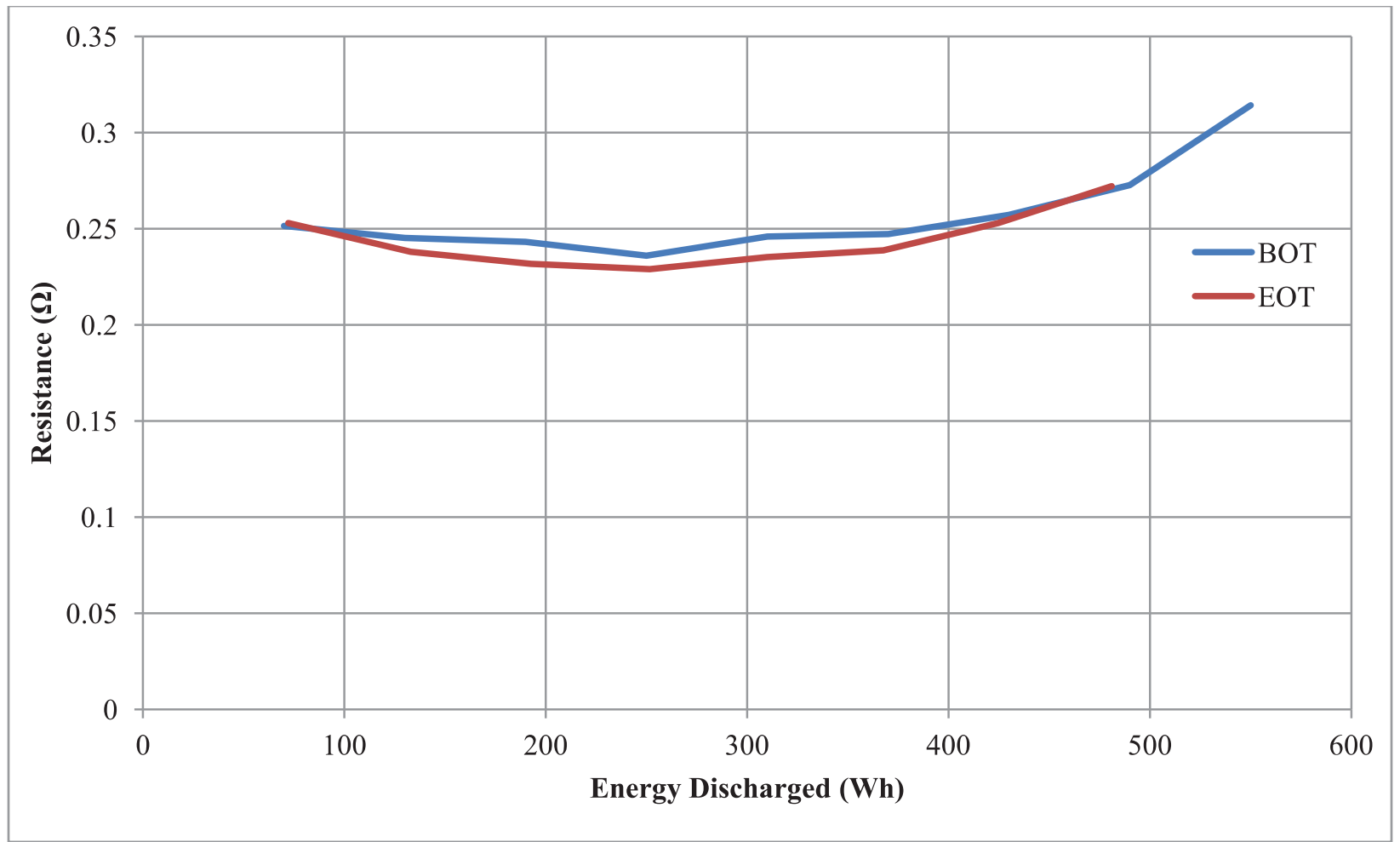

Figure 2. Ten-second charge pulse resistance versus energy discharged.

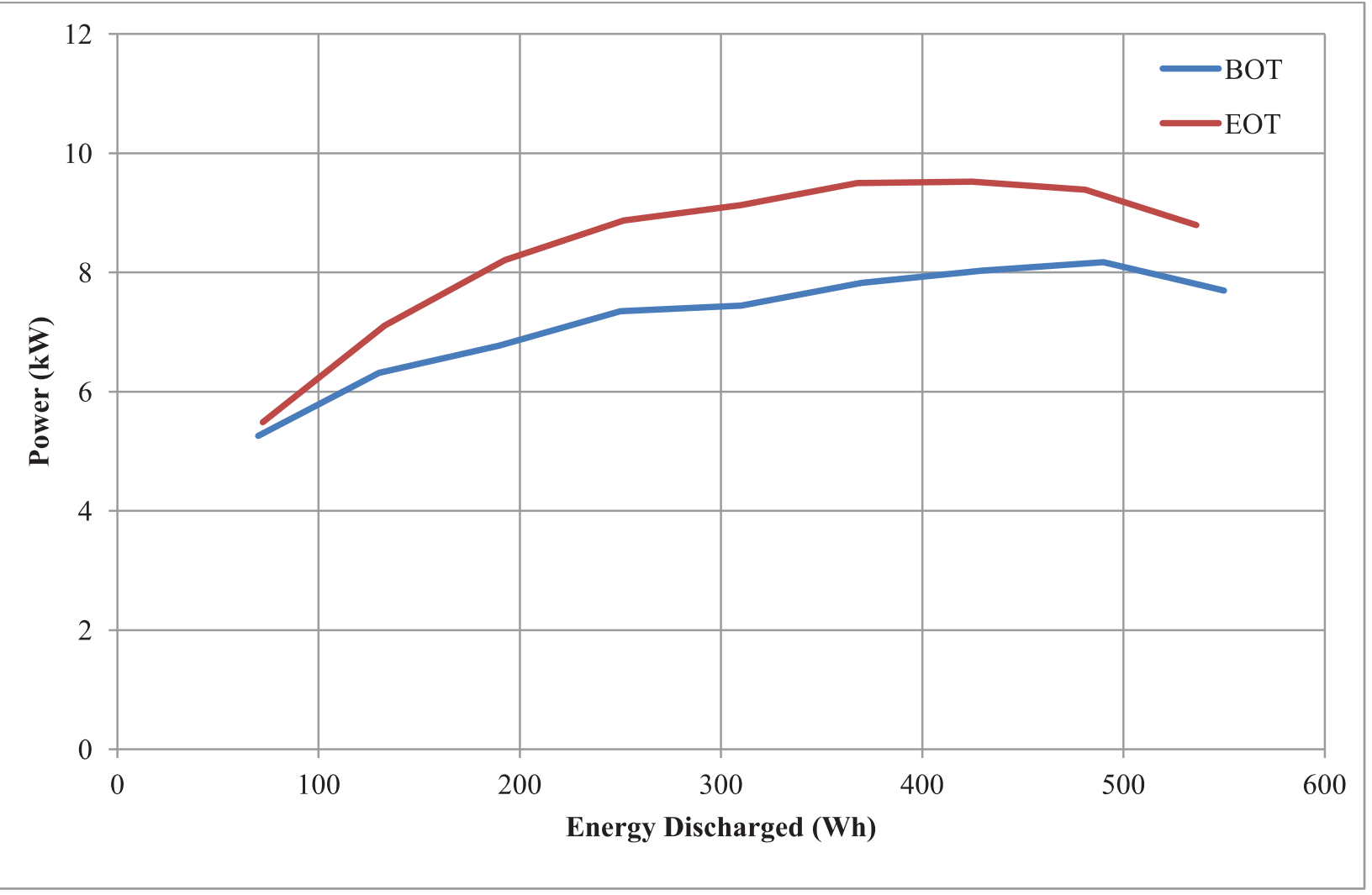

Figure 3. Ten-second charge pulse power capability versus energy discharged. 


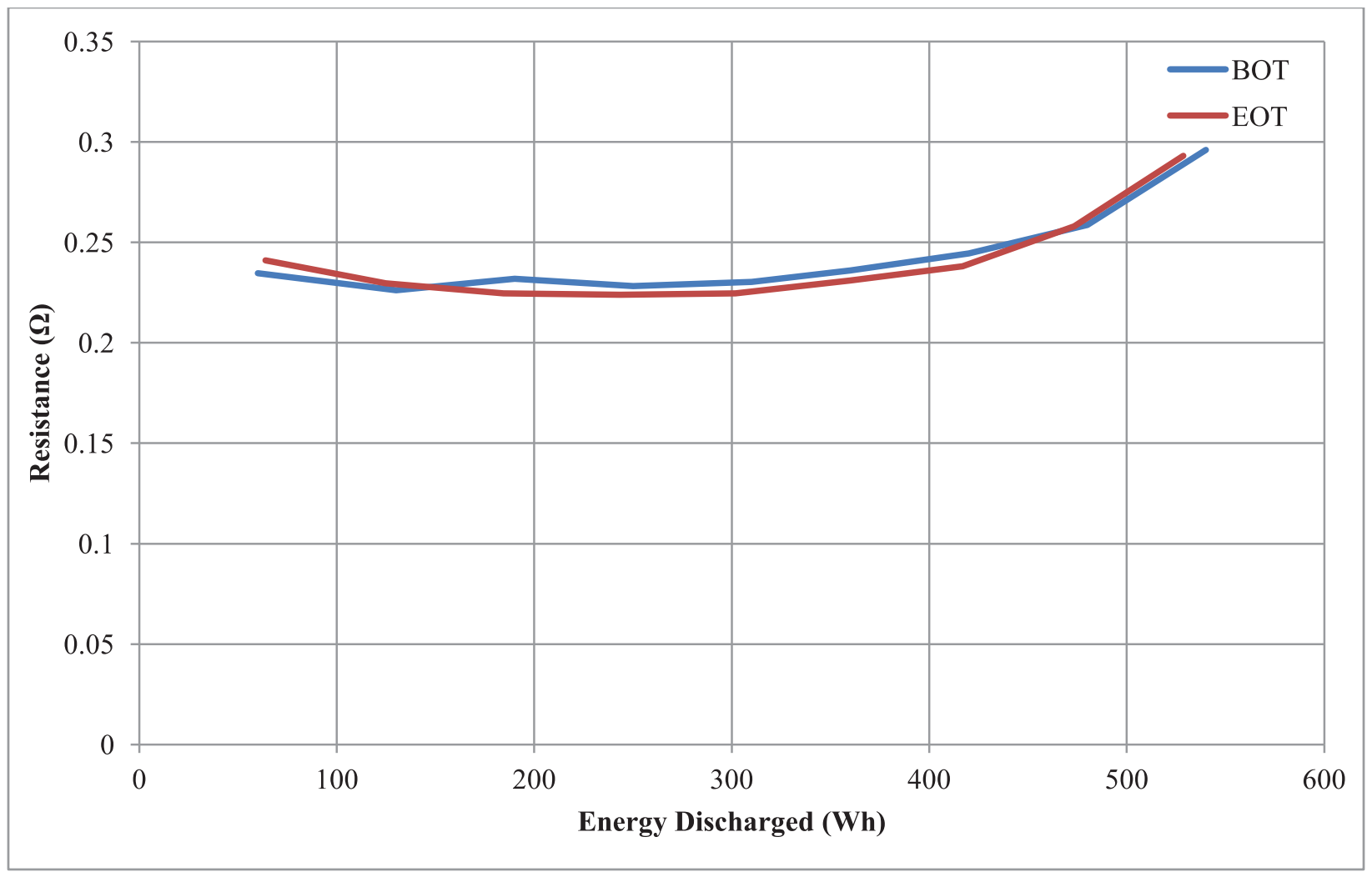

Figure 4. Ten-second discharge pulse resistance versus energy discharged.

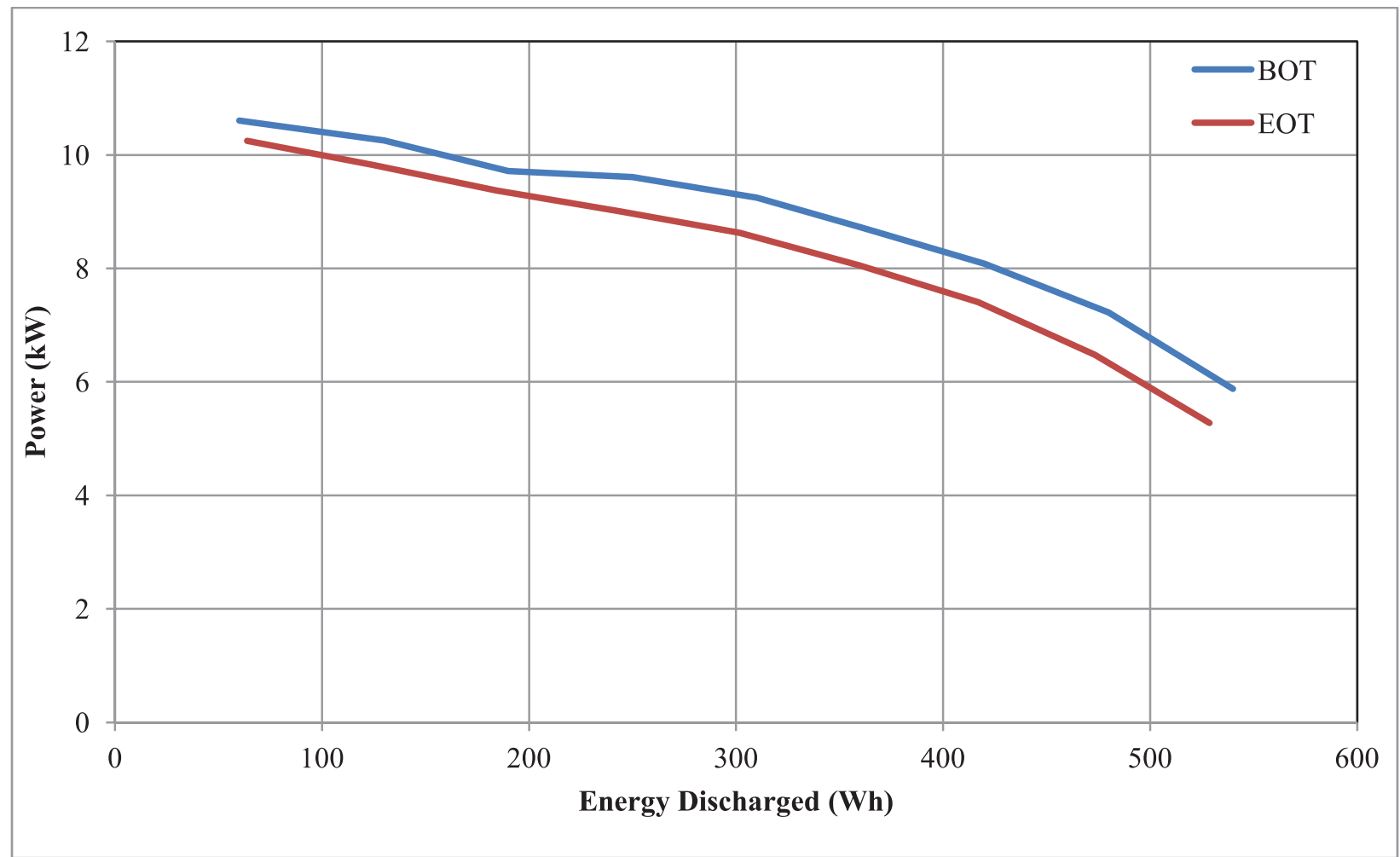

Figure 5. Ten-second discharge pulse power capability versus energy discharged. 
Figure 6 is a plot of the BOT and EOT HPPC 10-second pulse power capability values of the battery as a function of energy discharged. The graph shows the power values over the range of energy discharged. The DOE targets for a hybrid power-assist battery for discharge power $(25 \mathrm{~kW})$ and regenerative power $(20 \mathrm{~kW})$ are included for comparative purposes. Neither the BOT nor the EOT battery tests meet the DOE power targets (denoted by the dashed line in the figure) for any battery energy discharged range.

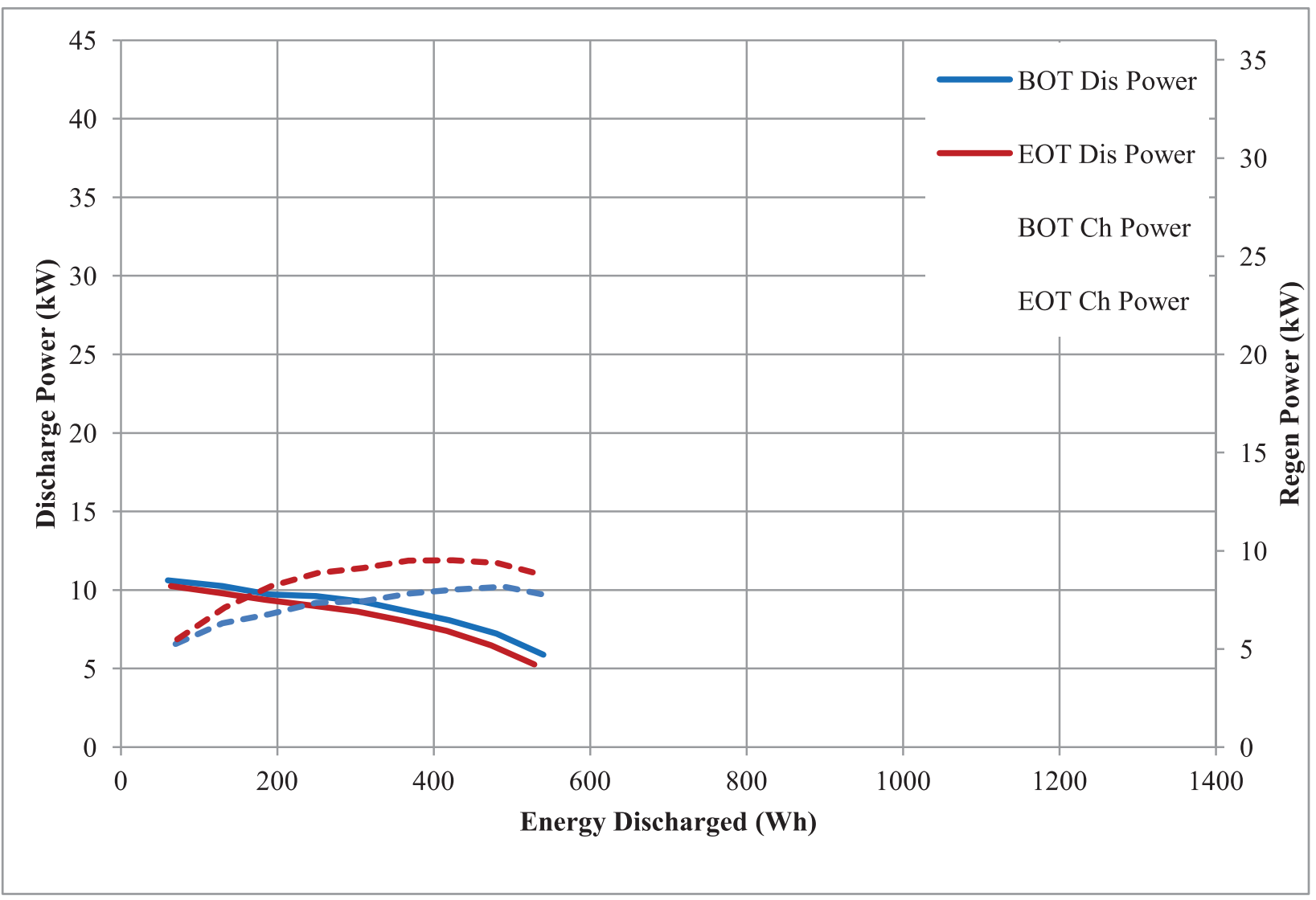

Figure 6. Peak discharge and regenerative power versus energy discharged.

Figure 7 is a plot of the BOT and EOT useable energy as a function of battery power. The x-axis indicates a desired discharge power level and the y-axis indicates the useable energy at that power. The dashed horizontal line shows the DOE minimum power-assist HEV energy target of $300 \mathrm{Wh}$. The dashed vertical line shows the DOE minimum power-assist discharge power target of $25 \mathrm{~kW}$. The BOT useable energy curve of the Insight battery falls above and to the left of the intersection of DOE's energy and power targets. The maximum power that can be delivered while meeting the DOE energy target is $7.7 \mathrm{~kW}$ at $300 \mathrm{Wh}$. The DOE power target of $25 \mathrm{~kW}$ was outside the useable power delivered during testing. This indicates that at the time of BOT testing, the Insight battery performance was below DOE targets. The EOT useable energy curve of the battery falls above and to the left of the intersection of the DOE energy and power targets. The maximum power that can be delivered while meeting the DOE energy target is 7.6 $\mathrm{kW}$ at $300 \mathrm{Wh}$. Over the entire range of usable energy, the DOE power target of $25 \mathrm{~kW}$ was not achieved. This indicates that at the time of EOT testing, the Insight battery performance was below DOE targets. 


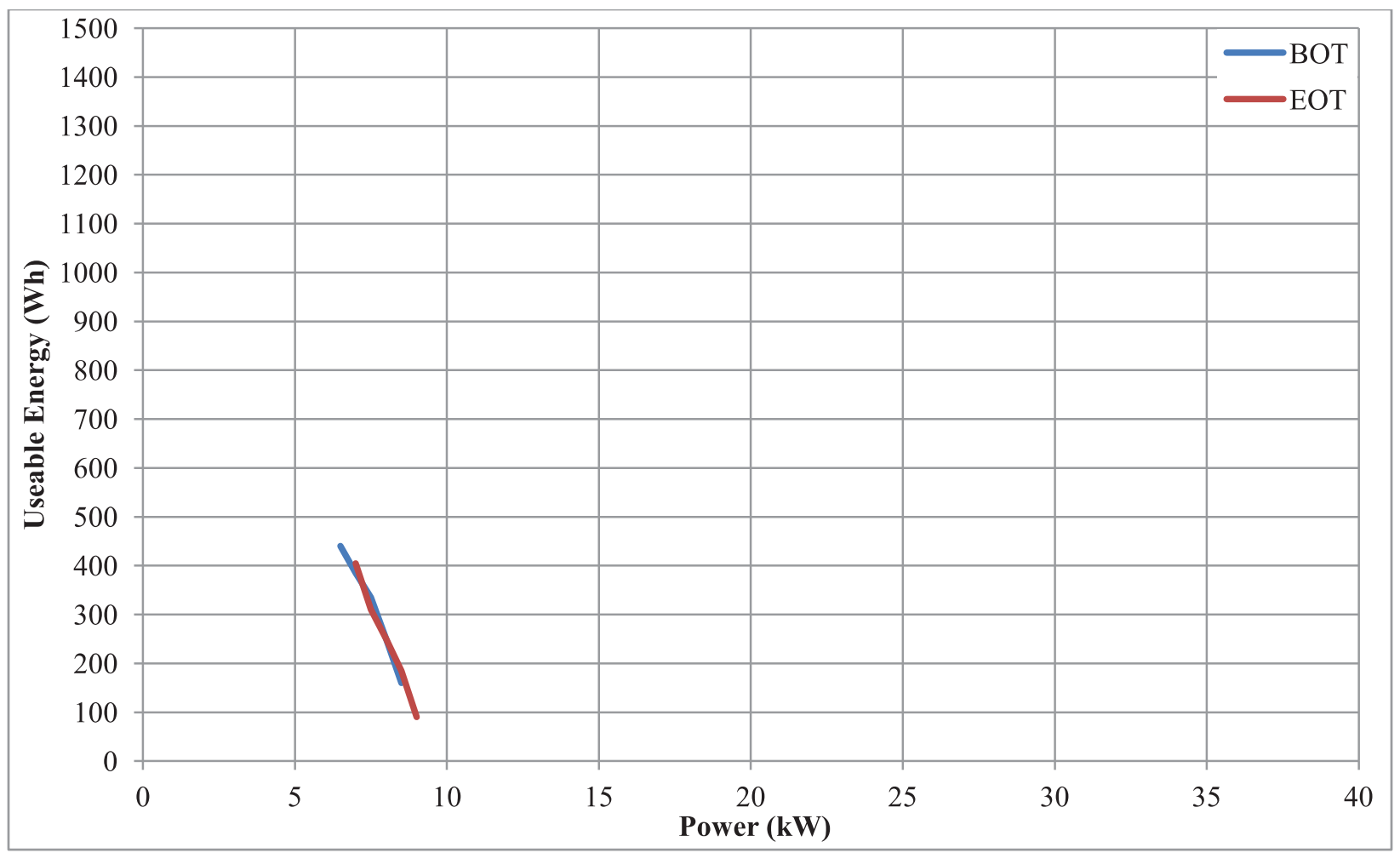

Figure 7. Useable energy versus power.

\subsection{Acceleration Test Results}

BOT and EOT results from vehicle on-track acceleration tests are summarized in Table 3. The BOT testing was conducted on a similar Insight with VIN 0141.

Table 3. Acceleration test results for beginning-of-test and end-of-test on-track acceleration.

\begin{tabular}{lcccccc}
\hline & $\begin{array}{c}\text { Average } \\
\text { Discharge } \\
\text { Power Over } \\
\text { 10s (kW) }\end{array}$ & $\begin{array}{c}\text { Energy } \\
\text { Discharged } \\
\text { at 1 Mile } \\
\text { (Wh) }\end{array}$ & $\begin{array}{c}\text { Capacity } \\
\text { Discharged } \\
\text { at 1 Mile } \\
\text { (Ah) }\end{array}$ & $\begin{array}{c}\text { Peak Power } \\
\text { Over 1 Mile } \\
(\mathbf{k W})\end{array}$ & $\begin{array}{c}\text { Minimum } \\
\text { Discharge } \\
\text { Pack } \\
\text { Voltage (V) }\end{array}$ & $\begin{array}{c}\text { Minimum } \\
\text { Discharge } \\
\text { Cell Voltage } \\
\text { (V) }\end{array}$ \\
\hline BOT & 8.06 & 107 & 1.13 & 10.7 & 86.8 & 1.03 \\
EOT & 9.73 & 106 & 1.16 & 11.3 & 85.1 & 1.01 \\
\hline
\end{tabular}

Figure 8 shows battery power versus time during the 1-mile acceleration test at EOT and BOT. This graph is the basis for power calculations over specified time or distance intervals and the cumulative discharged energy capacity during the duration of the test. At the beginning of the acceleration test, the power quickly increases from approximately $0 \mathrm{~kW}$ to a peak value. The power then remains relatively constant until battery or vehicle system dynamics, which may include battery control logic, cause a reverse in power direction to charge the battery.

Figure 9 shows the battery voltage versus time during the 1-mile acceleration test at BOT and EOT. Values are analyzed to determine the minimum voltage allowed by the battery control module, if possible. Although the test may not yield a definitive minimum voltage value, it can provide an approximation for comparison to the HPPC analysis results. This graph also shows the impact of power electronics and battery controller on the voltage response. 


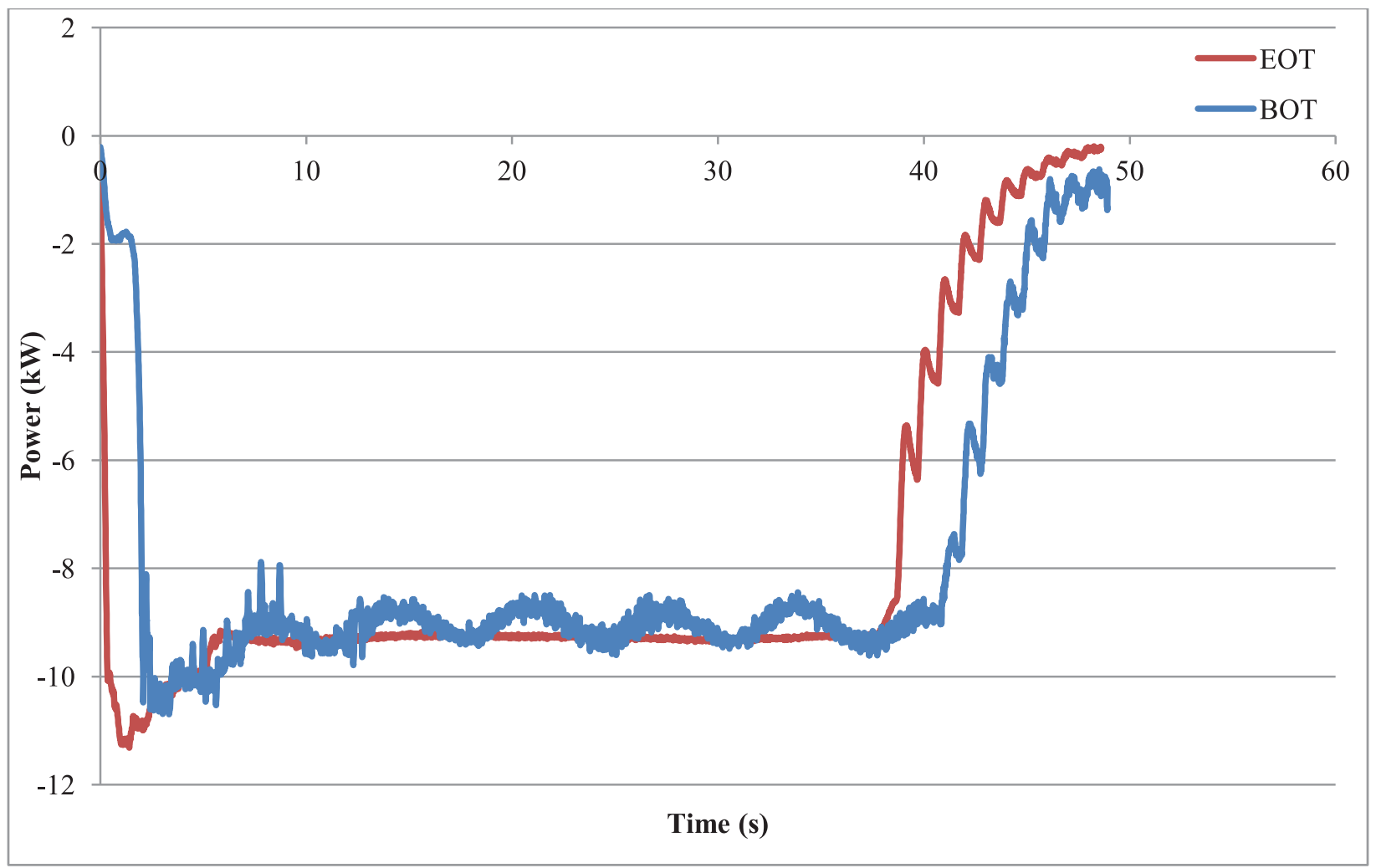

Figure 8 . Battery power versus time from acceleration testing.

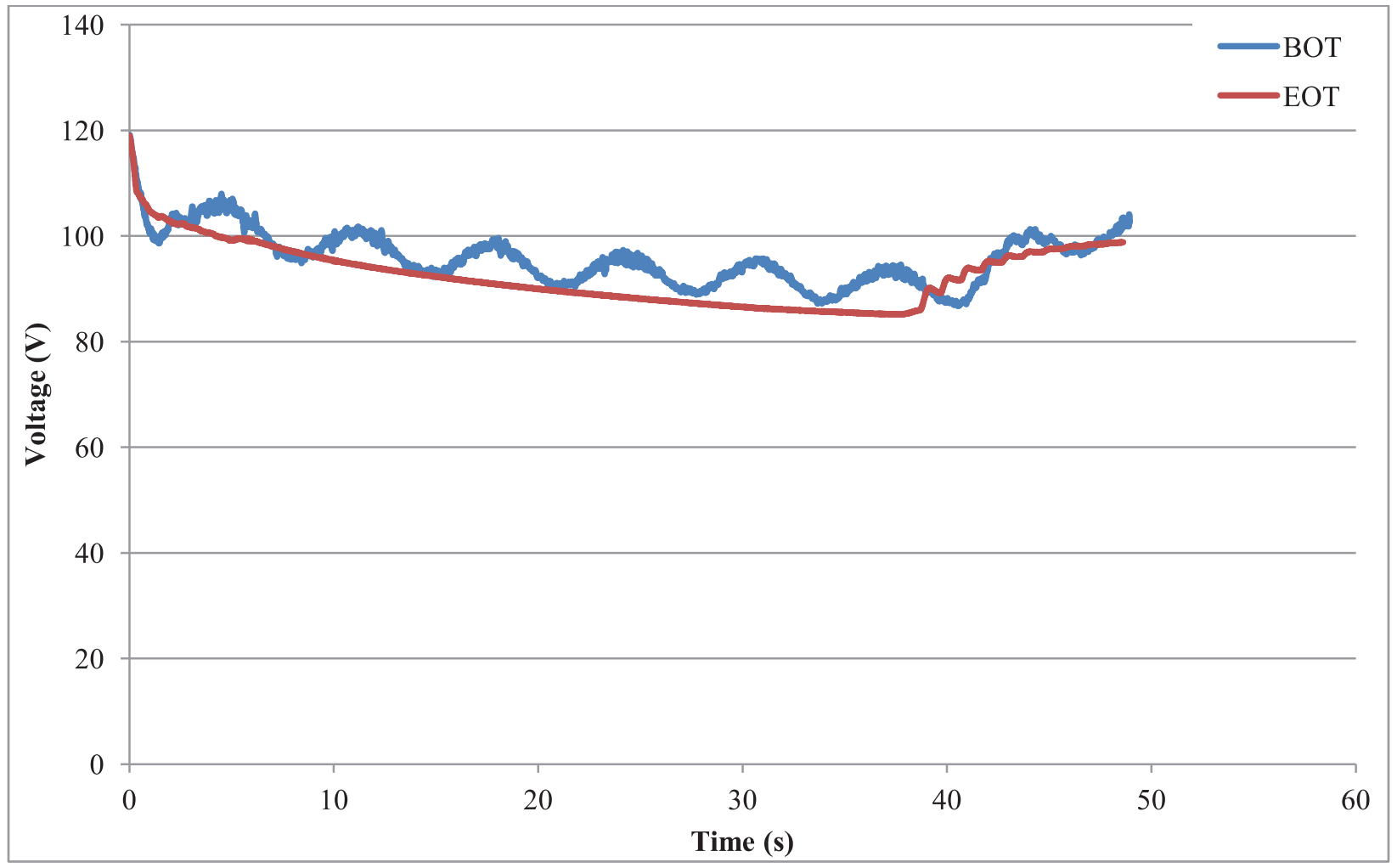

Figure 9. Battery voltage versus time from acceleration testing. 
Figure 10 shows battery current versus time during the 1-mile acceleration test at BOT and EOT. This graph also is the basis for determining the discharged capacity during the test run. Lastly, the power results in Figure 8 can be obtained by simply multiplying the voltage values from Figure 9 by the current values in Figure 10.

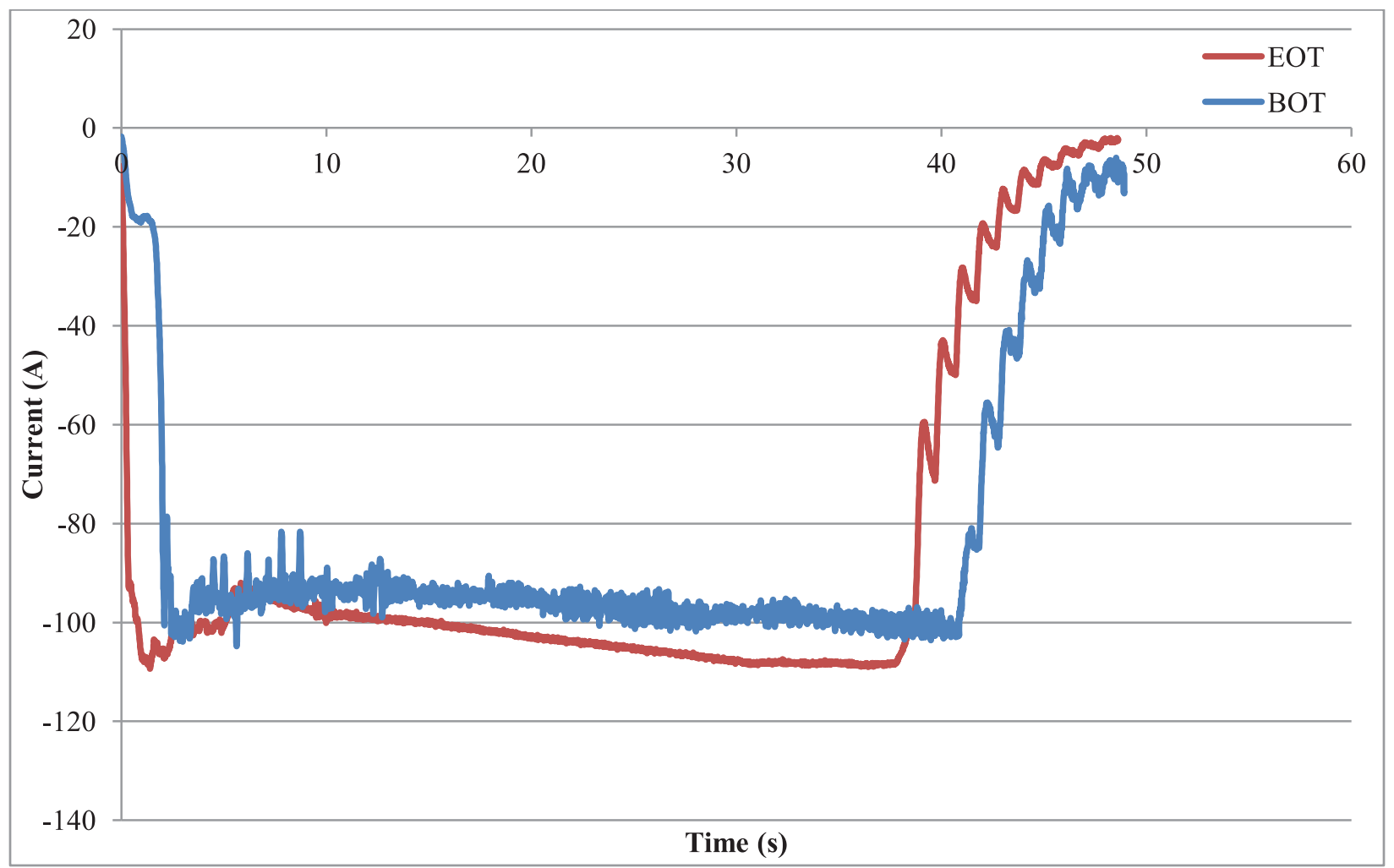

Figure 10. Battery current versus time from acceleration testing.

\subsection{Fuel Economy Test Results}

Battery performance results from testing conducted on a chassis dynamometer (using the Urban Dynamometer Drive Schedule ${ }^{5}$ ) at BOT and average fuel economy recorded while the vehicle was operating in an on-road fleet ${ }^{6}$, with approximately $49.9 \%$ city $^{7}$ and $50.1 \%$ highway routes. Battery performance and fuel economy results are summarized in Table 4.

Table 4. Battery performance results from the Urban Dynamometer Drive Schedule dynamometer drivecycle testing.

\begin{tabular}{|l|c|l|c|}
\hline Peak Discharge Power (kW): & 6.01 & Maximum Regen Pack Voltage (V): & 127.8 \\
\hline Peak Regen Power (kW): & 7.81 & Maximum Regen Cell Voltage (V): & 1.52 \\
\hline Measured Discharge Capacity (Ah): & 5.84 & Minimum Discharge Pack Voltage (V): & 102.8 \\
\hline Measured Regen Capacity (Ah): & 5.58 & Minimum Discharge Cell Voltage (V): & 1.22 \\
\hline Discharge/Regen Ratio: & 1.047 & Average Fuel Economy (mpg): & 40.4 \\
\hline
\end{tabular}

\footnotetext{
${ }^{5}$ The Urban Dynamometer Drive Schedule was performed as defined by the Environmental Protection Agency. The definition of the Urban Dynamometer Drive Schedule can be found at http://www.epa.gov/nvfel/methods/uddsdds.gif.

${ }^{6}$ On-road fleet testing is performed by ECOtality North America (in conjuncture with EZ-Messenger courier services). The vehicles are driven on a combination of city and highway routes by several different drivers to expedite the mileage accumulation required to reach EOT.

${ }^{7}$ City routes are determined as trips with an average speed less than $42 \mathrm{mph}$.
} 
Figure 11 illustrates the vehicle motive power and battery power histograms throughout one of the tested drive schedules. Motive power is a calculated value representing the instantaneous theoretical positive wheel power required to complete the urban drive cycle. The $\mathrm{x}$-axis of the bar graph represents the center point of a particular power level. For example, the first bar on the graph with a power of $2 \mathrm{~kW}$ represents all power values between 1 and $3 \mathrm{~kW}$ (lower boundary is inclusive and upper boundary is non-inclusive). The corresponding $y$-value at this power level is the percentage of time at this particular power band throughout the entire drive cycle (regeneration power and zero power non-inclusive). While the occurrences of vehicle motive power and battery discharge power in each power band in Figure 11 are not necessarily coincident in time, it is possible to conclude from the overall shapes of the distributions that the battery provides a small fraction of the required vehicle motive power. Efficiency losses between the battery and wheels are not included in this figure; they naturally reduce the contribution of the battery to vehicle motive power.

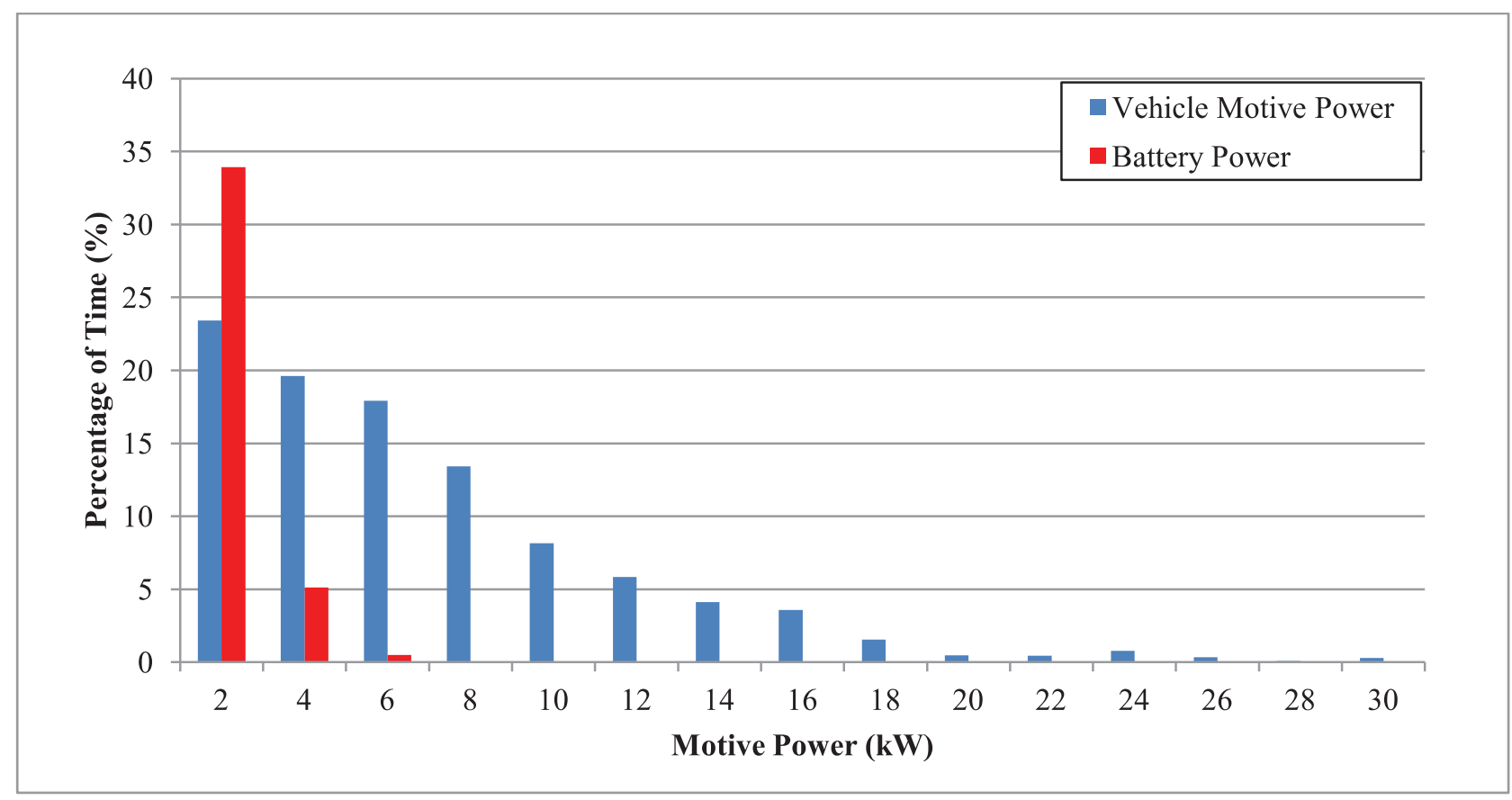

Figure 11. Percentage of time at motive power level.

Figure 12 illustrates the vehicle potential regenerative braking power histogram throughout one of the tested urban drive cycles. Vehicle potential regenerative braking power is a calculated value that represents the theoretical negative wheel power required to decelerate the vehicle on the urban drive cycle. Figure 12 compares the distributions of available braking power and actual battery charge power in a similar manner to Figure 11. The overall shapes of the distributions indicate that the battery captures the lower end of the power range at a substantial fraction of the vehicle power available during braking.

Figure 13 is a pie chart showing the sources of battery charging. The chart shows the percentages of battery charging time when the battery experienced ideal versus non-ideal charging. Ideal charging refers to regenerative braking during deceleration, where the deceleration force is in excess of the vehicle drag forces. On a non-hybrid vehicle, this would require the brakes to be engaged and excess energy would be converted to heat at the brakes. In a hybrid vehicle, a portion of this excess energy can be captured and stored for later use through regenerative braking. Because this charge method is capturing energy that is normally lost, the charge event is considered ideal. The second charging type is called non-ideal because the vehicle charges the battery through use of the internal combustion engine and generator. This can happen during acceleration, cruising, or deceleration, when excess engine load is available or when the battery state of charge has dropped below a minimum level. This is non-ideal because the internal 
combustion engine charges the battery. In some cases, this can be beneficial for overall fuel economy by maintaining optimum load on the engine to increase efficiency; however, it is still considered non-ideal (by definition) because gasoline is used to charge the batteries.

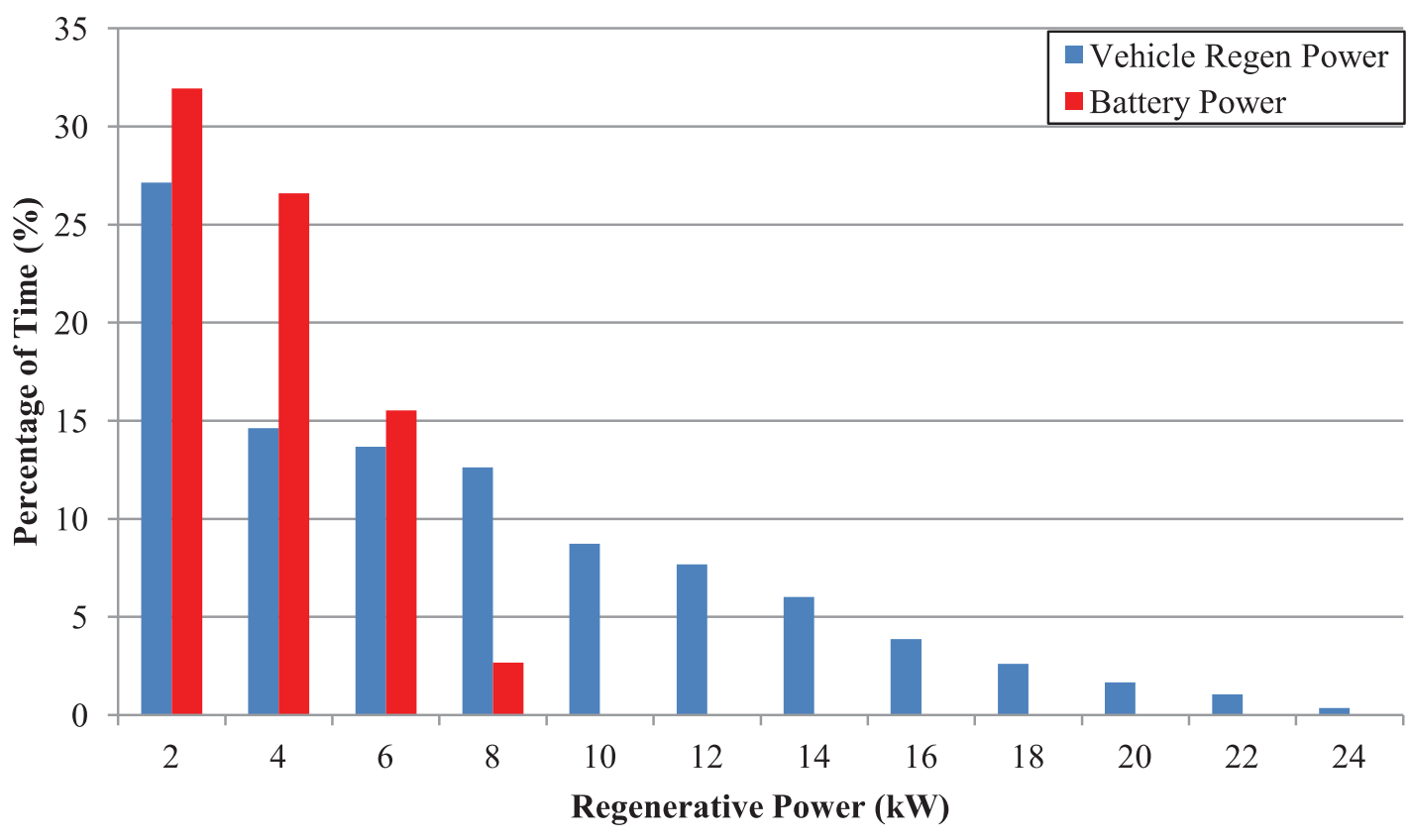

Figure 12. Percentage of time at regenerative power level.

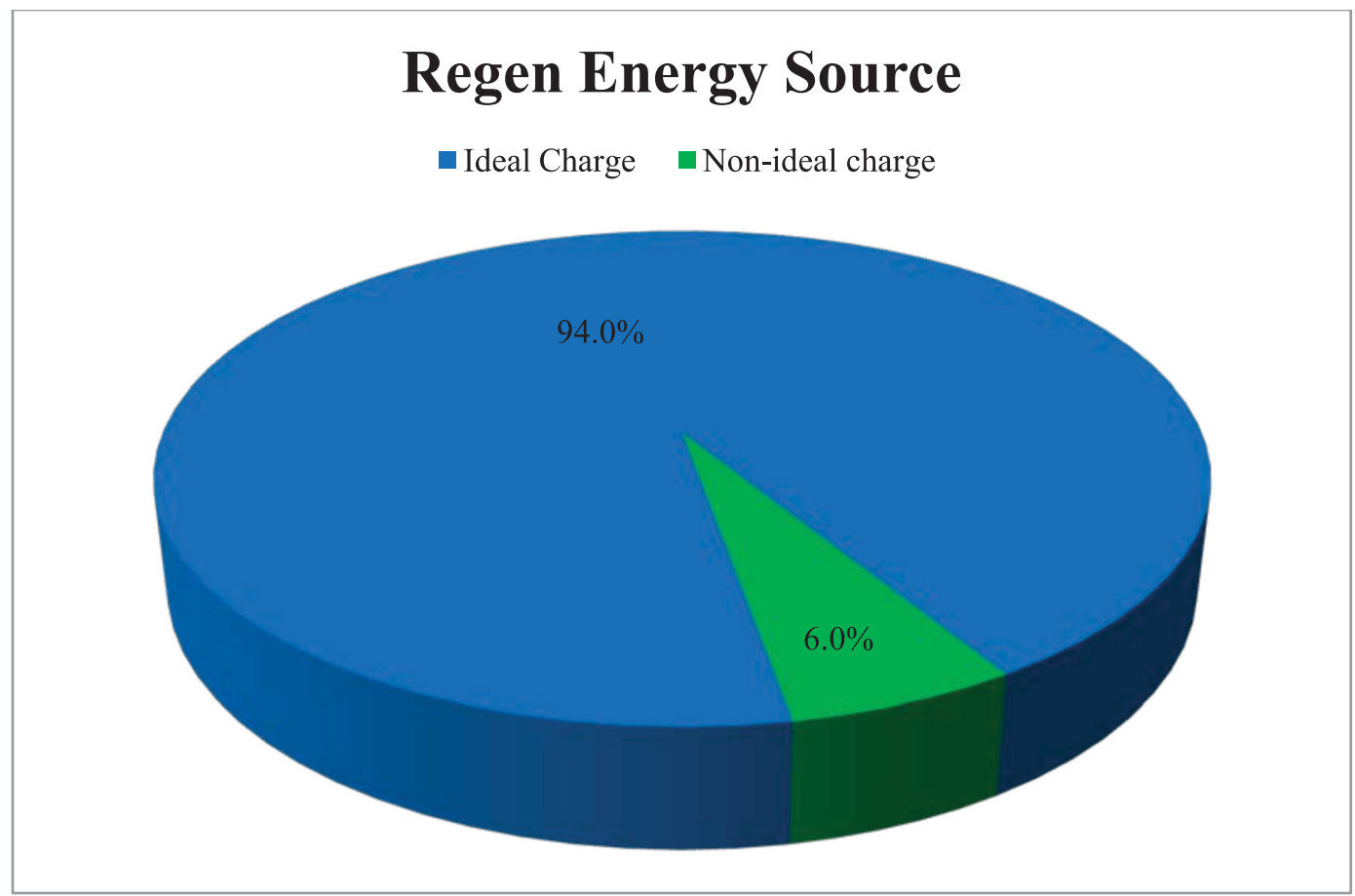

Figure 13. Regenerative energy source comparison. 
Figure 14 is a pie graph that shows the percentage of vehicle regeneration energy captured in the battery. By calculating the total vehicle energy available at the wheels during an ideal charge event and performing a direct comparison of energy into the battery, the percent energy into the battery can be calculated. In addition, system losses can be determined as the difference between energy available from the vehicle and energy into the battery. Although each component of loss cannot be determined, the total system loss can be measured by this method. Also, it should be noted that this calculation does not take into account losses at the battery due to charge inefficiency and that the charge current limitations of the battery may prevent all of the regenerative energy from being captured, thus forcing the use of friction braking. This measurement is merely a calculation of how efficiently the vehicle charging mechanism is able to capture regeneration energy during an ideal charge event. ${ }^{8}$

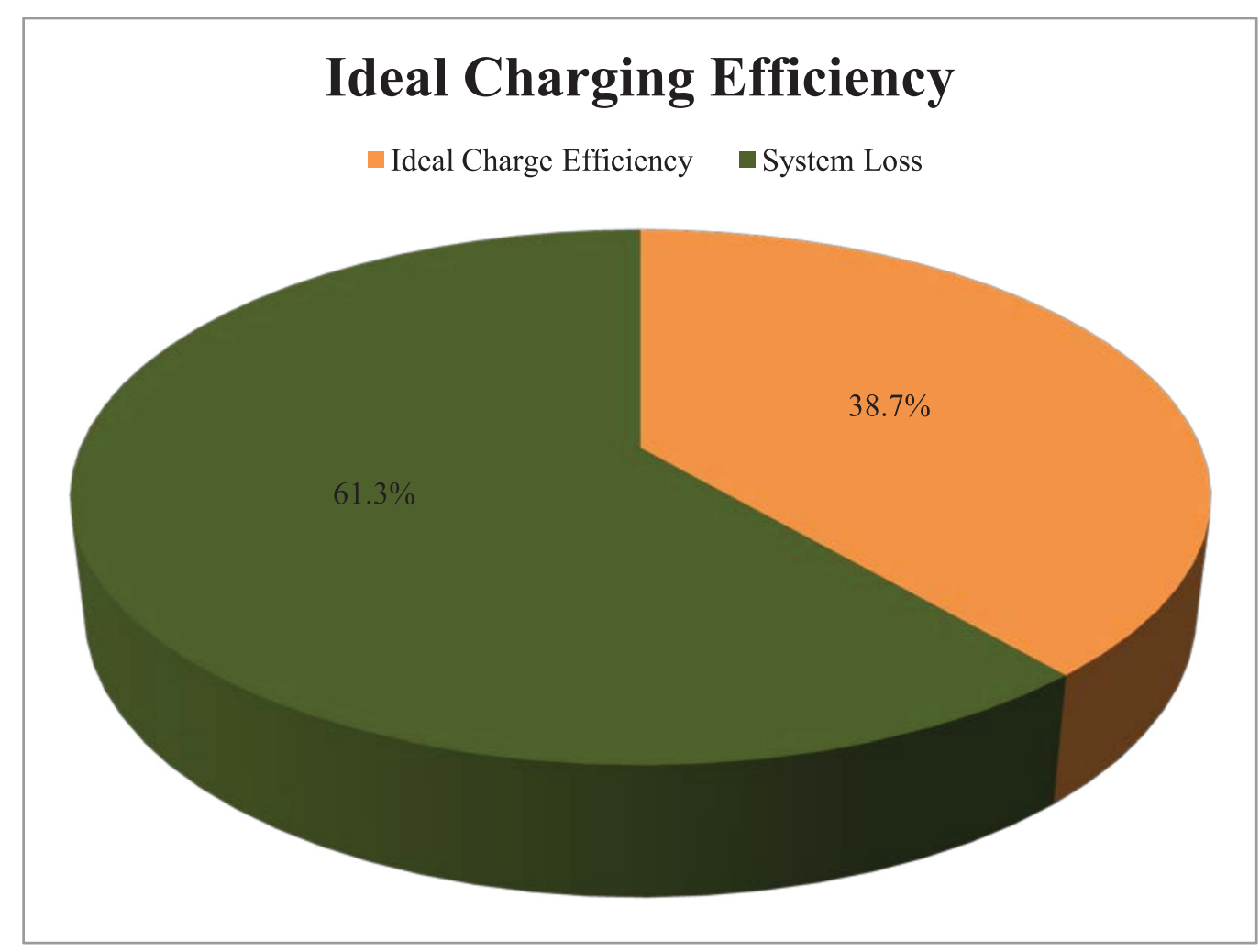

Figure 14. Regenerative energy efficiency.

Figure 15 presents the combined monthly fuel economy and cumulative fuel economy for the two Insight HEVs, VIN 0141 and VIN 1748, that underwent on-road fleet testing. The monthly fuel economy is derived from the amount of fuel consumed, based on fleet fueling records, and the distance traveled, based on vehicle odometer readings, for each vehicle within that month. The cumulative fuel economy is a running total of each month's fuel consumption and distance traveled. While the vehicle's fuel economy cannot be directly correlated to operation of the battery pack with only these data, the vehicle fuel economy in Figure 15 steadily drops over the last 25 months of testing, even with no battery degradation demonstrated by the EOT battery test.

\footnotetext{
${ }^{8}$ Results shown in Figures 13 and 14 do not consider the case when non-ideal engine charging occurs during a regenerative braking event. The impact of this case during the Urban Dynamometer Drive Schedule test is assumed to be negligible.
} 


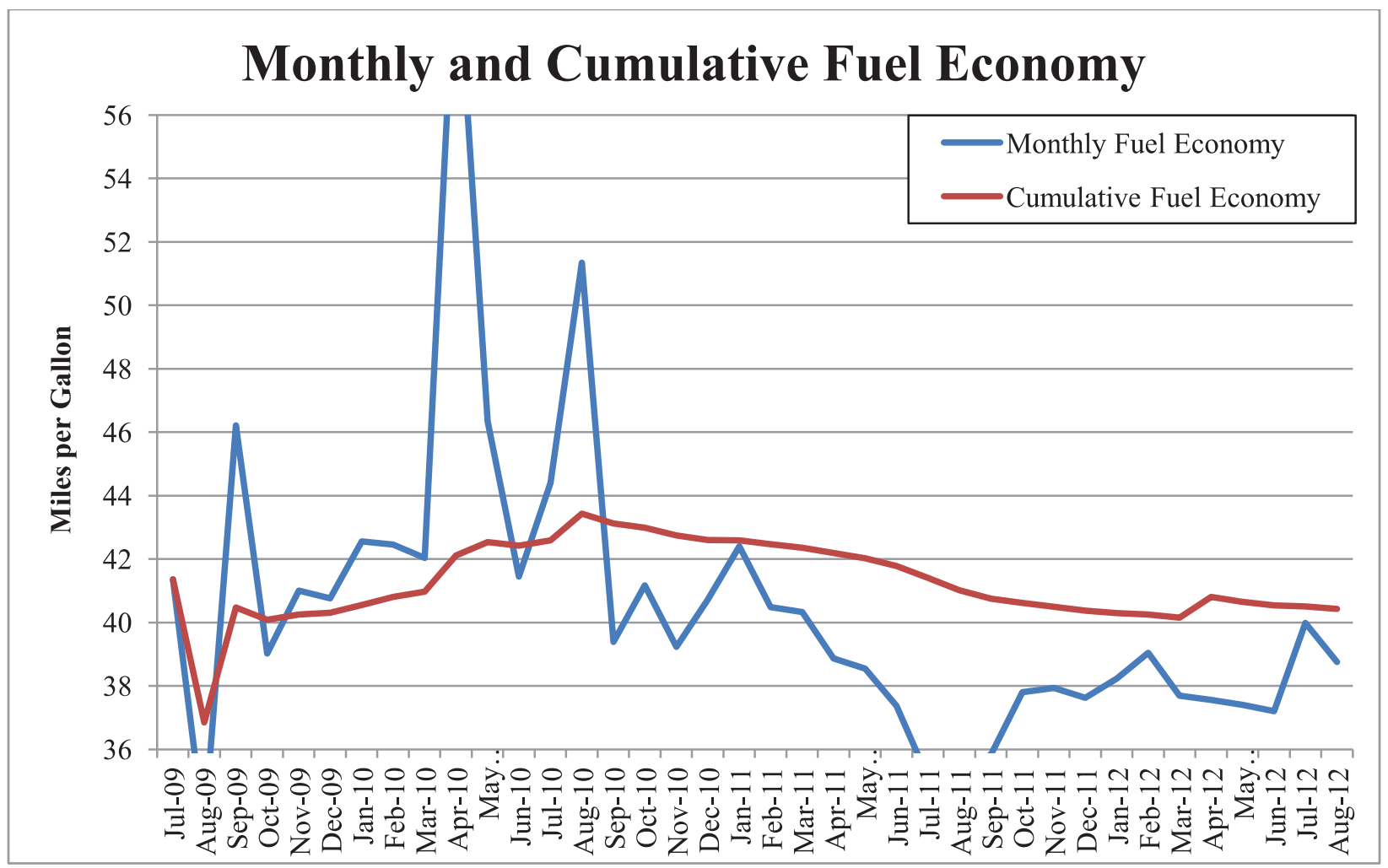

Figure 15. Monthly and cumulative fuel economy.

\subsection{Conclusion}

The Honda Insight, with VIN 1748, experienced a $0.9 \%$ increase in battery capacity and stayed below DOE targets for all aspects of the HPPC test over the duration of 160,000 miles of fleet testing. 


\section{Appendix A \\ Vehicle Specifications and Test Results Summary}

\begin{tabular}{|c|c|}
\hline Vehicle Specifications & Battery Specifications \\
\hline $\begin{array}{l}\text { Manufacturer: Honda } \\
\text { Model: Insight } \\
\text { Year: } 2010 \\
\text { Motor Power Ratinga: } 10 \mathrm{~kW} \\
\text { VIN \#: JHMZE2H59AS011748 }\end{array}$ & $\begin{array}{l}\text { Manufacturer: Panasonic } \\
\text { Battery Type: Nickel-Metal Hydride } \\
\text { Rated Capacity: } 5.75 \mathrm{Ah} \\
\text { Nominal Pack Voltage: } 100.8 \text { VDC } \\
\text { Nominal Cell Voltage: } 1.2 \mathrm{~V} \\
\text { Number of Cells: } 84\end{array}$ \\
\hline \multicolumn{2}{|c|}{ Beginning-of-Test Vehicle Baseline Performance Test Results ${ }^{\mathrm{b}}$} \\
\hline $\begin{array}{l}\text { Acceleration Test } \\
\text { Average Discharge Power Over 10 seconds }: 8.06 \mathrm{~kW} \\
\text { Peak Discharge Power Over 1 mile: } 10.7 \mathrm{~kW} \\
\text { Energy Discharged @1 mile }{ }^{\mathrm{d}}: 107 \mathrm{Wh} \\
\text { Capacity Discharged @1 mile }: 1.13 \mathrm{Ah} \\
\text { Minimum Discharge Pack Voltage: } 86.8 \mathrm{VDC} \\
\text { Minimum Discharge Cell Voltage: } 1.03 \mathrm{~V}\end{array}$ & \begin{tabular}{l}
\multicolumn{1}{c}{ Fuel Economy Test } \\
Peak Discharge Power: $6.01 \mathrm{~kW}$ \\
Peak Regen Power: $7.81 \mathrm{~kW}$ \\
Measured Discharge Capacitye: $5.84 \mathrm{Ah}$ \\
Measured Regen Capacity: $5.58 \mathrm{Ah}$ \\
Battery Discharge/Regen Ratiof: 1.047 \\
Maximum Regen Pack Voltage: $127.8 \mathrm{VDC}$ \\
Maximum Regen Cell Voltage: $1.52 \mathrm{Vpc}$ \\
Minimum Discharge Pack Voltage: $102.8 \mathrm{VDC}$ \\
Minimum Discharge Cell Voltage: $1.22 \mathrm{Vpc}$ \\
\end{tabular} \\
\hline \multicolumn{2}{|c|}{ End-of-Test Vehicle Baseline Performance Test Results } \\
\hline \multicolumn{2}{|c|}{ Acceleration Test } \\
\hline \multicolumn{2}{|c|}{$\begin{array}{c}\text { Average Discharge Power Over } 10 \text { seconds }^{\mathrm{c}}: 9.73 \mathrm{~kW} \\
\text { Peak Discharge Power Over } 1 \text { mile: } 11.3 \mathrm{~kW} \\
\text { Energy Discharged @ } 1 \text { mile }^{\mathrm{d}}: 106 \mathrm{Wh} \\
\text { Capacity Discharged @ } 1 \text { mile }{ }^{\mathrm{d}}: 1.16 \mathrm{Ah} \\
\text { Minimum Discharge Pack Voltage: } 85.1 \mathrm{VDC} \\
\text { Minimum Discharge Cell Voltage: } 1.01 \mathrm{~V} \\
\end{array}$} \\
\hline \multicolumn{2}{|c|}{ Beginning-of-Test Battery Laboratory Test Results } \\
\hline $\begin{array}{l}\text { Hybrid Pulse Power Characterization Test } \\
\text { Peak Pulse Discharge Power @ } 10 \text { seconds }^{\mathrm{g}}: 9.24 \mathrm{~kW} \\
\text { Peak Pulse Discharge Power @ 1 second } \mathrm{g}^{\mathrm{g}}: 15.1 \mathrm{~kW} \\
\text { Peak Pulse Charge Power @ } 10 \text { seconds }^{\mathrm{g}}: 7.44 \mathrm{~kW} \\
\text { Peak Pulse Charge Power @ } 1 \text { second }: 12.2 \mathrm{~kW} \\
\text { Maximum Cell Charge Voltage: } 1.48 \mathrm{~V} \\
\text { Minimum Cell Discharge Voltage: } 1.00 \mathrm{~V}\end{array}$ & \begin{tabular}{l}
\multicolumn{1}{c}{ Static Capacity Test } \\
Measured Average Capacity: 5.66 Ah \\
Measured Average Energy Capacity: $600 \mathrm{Wh}$ \\
Vehicle Odometer: 24 miles \\
Date of Test: July 6, 2009
\end{tabular} \\
\hline \multicolumn{2}{|c|}{ End-of-Test Battery Laboratory Test Results } \\
\hline $\begin{array}{l}\text { Hybrid Pulse Power Characterization Test } \\
\text { Peak Pulse Discharge Power @ } 10 \text { seconds }^{\mathrm{g}}: 9.82 \mathrm{~kW} \\
\text { Peak Pulse Discharge Power @ } 1 \text { second }^{\mathrm{g}}: 13.4 \mathrm{~kW} \\
\text { Peak Pulse Charge Power @ } 10 \text { seconds }^{\mathrm{g}}: 9.13 \mathrm{~kW} \\
\text { Peak Pulse Charge Power @ } 1 \text { second }: 16.3 \mathrm{~kW} \\
\text { Maximum Cell Charge Voltage: } 1.48 \mathrm{~V} \\
\text { Minimum Cell Discharge Voltage: } 1.00 \mathrm{~V}\end{array}$ & \begin{tabular}{l}
\multicolumn{1}{c}{ Static Capacity Test } \\
Measured Average Capacity: 5.71 Ah \\
Measured Average Energy Capacity: $590 \mathrm{Wh}$ \\
Vehicle Odometer: 160,016 miles \\
Date of Test: April 6, 2012
\end{tabular} \\
\hline
\end{tabular}




\begin{tabular}{|c|c|}
\hline \multicolumn{2}{|c|}{ Degradation of Battery Over Test Period ${ }^{\mathrm{h}}$} \\
\hline Hybrid Pulse Power Characterization Test & Static Capacity Test \\
\hline $\begin{array}{l}\text { Peak Pulse Discharge Power @ } 10 \text { seconds }^{\mathrm{g}}:-0.58 \mathrm{~kW}(-6.2 \%) \\
\text { Peak Pulse Discharge Power @ } 1 \text { second }^{\mathrm{g}}: 1.7 \mathrm{~kW}(11 \%) \\
\text { Peak Pulse Charge Power @ } 10 \text { seconds } \\
\text { Peak Pulse Charge Power @ } 1 \text { 1 second } d^{\mathrm{g}}:-4.1 \mathrm{~kW}(-33 \%) \\
\end{array}$ & $\begin{array}{l}\text { Measured Average Capacity: }-0.05 \text { Ah }(-0.9 \%) \\
\text { Measured Average Energy Capacity: } 10 \mathrm{Wh}(1.6 \%)\end{array}$ \\
\hline $\begin{array}{l}\text { Notes: } \\
\text { a. Motor power rating refers to the manufacturer's peak power rating } \\
\text { b. Vehicle test results are derived from baseline testing of Insight VI } \\
\text { c. The peak power at a specified duration is the average power value } \\
\text { d. The capacitylenergy value is defined as the net value over a 1-mil } \\
\text { e. Cumulative capacity measurement over two hot start urban drive } \\
\text { f. Ratio is calculated as the ratio of measured capacity discharge to } 1 \\
\text { charge are not specifically known, but are controlled by the batter } \\
\text { g. Calculated value based on selected battery voltage limits and at } 50 \\
\text { h. Alling. }\end{array}$ & $\begin{array}{l}\text { or the motor(s) supplying traction power. } \\
0141 . \\
\text { ver a specified interval. } \\
\text { full-throttle acceleration test. } \\
\text { cles and two hot start highway drive cycles. } \\
\text { asured capacity regenerated. The initial and final states of } \\
\text { management system and are within its normal range. } \\
\text { state of charge of measured capacity at the time of BOT } \\
\text { l laboratory test to final laboratory test. }\end{array}$ \\
\hline
\end{tabular}

